\title{
Lutero sobre la hagiografía y los hagiógrafos sobre Lutero*
}

\author{
Fernando Baños Vallejo \\ Universitat d'Alacant \\ banos@ua.es
}

Recepción: 26/02/2019, Aceptación: 06/06/2019, Publicación: 04/12/2019

\section{Resumen}

Había una tarea pendiente imprescindible para valorar en qué medida los principales hagiógrafos castellanos postridentinos, Alonso de Villegas y Pedro de Ribadeneira, actuaban movidos por la controversia europea sobre el culto a los santos y la hagiografía en el contexto de la Reforma: comparar sus declaraciones de propósito y sus alusiones a los protestantes con los textos pertinentes de Lutero y sus afines, por un lado, y sus antagonistas católicos, por otro. Así que este trabajo ha consistido en identificar esos textos, localizarlos, extractarlos y, en su caso, traducirlos, para ponerlos en relación.

Las conclusiones que se derivan de tal ejercicio comparativo son que, según el plano al que atendamos, hallamos matices de coincidencia entre ambos bandos tan virulentamente enfrentados, tanto en lo que se refiere al aprecio de los santos, como respecto a la hagiografía, que los protestantes también terminan haciendo suya. Pero las diferencias acaban pesando más, porque la manipulación protestante de la hagiografía es rechazada por los católicos, que se atienen a la hagiografía autorizada por la tradición de la Iglesia, milagros incluidos, como es el caso de Villegas y Ribadeneira, en la senda del italiano Luis Lippomano y del alemán Lorenzo Surio.

Palabras clave

Flos sanctorum; hagiografía; Lutero; Reforma; Alonso de Villegas; Pedro de Ribadeneira; Luis Lippomano; Lorenzo Surio

\footnotetext{
* Trabajo desarrollado en el marco del proyecto de investigación «La hagiografía hispánica ante la Reforma protestante» (FFI2017-86248-P) del Ministerio de Economía, Industria y Competitividad.
} 


\begin{abstract}
Luther on Hagiography and Hagiographers on Luther

There was a remaining task necessary to assess to what extent the principal post-Tridentine Castilian hagiographers, Alonso de Villegas and Pedro de Ribadeneira, were moved by the European controversy on the cult of saints and hagiography in the context of the Reformation: to compare their declarations of purpose and their allusions to the Protestants with the pertinent texts of Luther and his affines, on the one hand, and their Catholic antagonists, on the other. So this work has consisted in identifying these texts, locating them, extracting them and translating them (when necessary), to put them in relation.

The conclusions deriving from such a comparative exercise are that, depending on the level we are dealing with, we find touches of agreement between both sides so virulently opposed, both in regard to the appreciation of the saints, and in regard to hagiography, that the Protestants also end up making theirs. But finally the differences weigh more, because the Protestant manipulation of the hagiography is rejected by the Catholics, who abide by the hagiography authorized by the tradition of the Church, including miracles, as is the case of Villegas and Ribadeneira, on the path of the Italian Luis Lippomano and the German Lorenzo Surio.
\end{abstract}

\title{
Keywords
}

Flos sanctorum; hagiography; Luther; Reformation; Alonso de Villegas; Pedro de Ribadeneira; Luigi Lippomano; Laurentius Surius

Alonso de Villegas y Pedro de Ribadeneira son conocidos como autores de los dos flores sanctorum castellanos más importantes del periodo postridentino. También es sabido que ambos declaran el propósito de llevar a cabo compilaciones depuradas de las adherencias apócrifas que pesaban sobre los santorales anteriores, ${ }^{1}$ ofrecer, en definitiva, lo que podríamos llamar una hagiografía crítica, ${ }^{2}$ un "Flos

1. Vid. al respecto Civil (1997), Aragüés (2000, 2005 y 2014), Arronis (2017) y Baños (2018).

2. Collins (2008: 133-136). 
sanctorum reformado", ${ }^{3}$ que sirva además de arma contra los herejes, vale decir protestantes. Pero hasta ahora no se había comprobado, y eso es precisamente el objetivo de estas páginas, de qué manera y en qué medida la declaración de intenciones de Villegas y Ribadeneira sigue la pauta de sus modelos principales, el italiano Luis Lippomano y el alemán Lorenzo Surio, y por tanto son reacción a las posiciones luteranas sobre el culto a los santos y el relato de sus vidas. Todos estos aspectos han de valorarse en el contexto del impacto de la Reforma sobre la hagiografía, que nos obliga, evidentemente, a trascender el ámbito de Castilla para verlos con una perspectiva europea y comparatista.

El procedimiento que había de seguirse para el logro de este objetivo parecía evidente: identificación y localización de los textos luteranos y católicos que participan de la controversia sobre los santos y la hagiografía, análisis de los prólogos y de la composición general de los libros, selección de los pasajes más pertinentes en relación con las declaraciones de Villegas y Ribadeneira, y traducción del latín al castellano para que, al yuxtaponer los extractos, se perciba fácilmente la relación. ${ }^{4}$ Lo mejor será dejar que los textos hablen por sí solos, y como al final no son pocas las líneas que me han parecido inexcusables para hacerse una idea cabal del asunto, reduciré al mínimo mis presentaciones y comentarios. Ordenaré cronológicamente las referencias y pasajes, a partir de Las noventa y cinco tesis (1517) de Lutero, que señalan el comienzo de su ruptura, hasta llegar al primer volumen de Ribadeneira, de manera que construiré una propuesta de la secuencia cronológica de la interacción entre autores protestantes y católicos en el tratamiento del culto a los santos y de la hagiografía. Terminaré con unas breves conclusiones que sinteticen las implicaciones de estos textos.

\section{7 (31 de octubre) Martín Lutero}

\section{Las noventa y cinco tesis}

Cuando Lutero proclama Las noventa y cinco tesis, que suelen considerarse el arranque del protestantismo, en verdad aún no ha roto con la Iglesia de Roma, y en lo que respecta al tema que nos ocupa se limita a mencionar en la tesis 58 los méritos de los santos. De ellos afirma, como de los de Cristo, que operan sin intervención del papa, de lo que colige que la Iglesia no puede disponer de

3. En la misma dedicatoria a Felipe II de la que más adelante se reproducen otras líneas, Villegas escribe: «Por lo cual con la censura y licencia de V. M. podrá tener nombre de Flos sanctorum reformado». 4. No me habría atrevido a ofrecer una traducción, por otro lado imprescindible, de estos textos latinos poco transitados y nunca, por lo que yo sé, vertidos a ninguna lengua moderna (con excepción de la Vida de san Jerónimo, de Erasmo, al inglés: Brady y Olin 1992), si no hubiera sido por la generosa ayuda de los latinistas Carmen Puche López, amiga y compañera, que ha revisado mis versiones, y de Gregorio de Gante, de la Universidad Nacional Autónoma de México, que ha aportado algunos matices. Cuando se trate de estas traducciones nuestras, incluyo en nota el texto original latino; las traducciones ajenas van sin acompańamiento del texto original. 
ellos como tesoro propio de buenas obras para generar las indulgencias. ${ }^{5}$ En todo caso, no se atisban las posteriores críticas ni mucho menos los ataques finales hacia el culto a los santos y a la Virgen.

\section{Erasmo de Rotterdam}

Como en otras materias, Erasmo de Rotterdam precedió a Lutero en la crítica de las devociones populares y de la hagiografía más milagrera y llamativa. Tanto es así que, de acuerdo con Heidrun Riehm, las primeras críticas de Lutero a las supersticiones sobre los santos no deben considerarse propias de la Reforma protestante, sino que se alinean con las críticas del humanismo a la piedad popular. ${ }^{6}$ No entran en el arco temporal que hemos establecido ni el Enchiridion (1501) ni el Elogio de la locura (1508), los textos más célebres de Erasmo, pero no puede pasarse por alto que en ellos ya denuncia ciertas prácticas devotas hacia los santos y sus reliquias y hacia la Madre de Dios como similares a las supersticiones de los adoradores de los dioses paganos, y critica que el vulgo se aficione más a las historias fabulosas sobre los santos que a los sermones serios, incluso si tratan sobre el mismísimo Jesucristo. Dos años después de que Lutero diera su aldabonazo en la iglesia de Witenberg, Erasmo publica una Vida de san Jerónimo. Ello podría parecer contradictorio con sus pronunciamientos contra las vidas de santos, pero no lo es, porque se trata de una hagiografía crítica. De hecho, según David J. Collins, ${ }^{7}$ a menudo se considera modelo de una nueva biografía sagrada del Renacimiento. De acuerdo con el análisis de Jacques Chomarat, ${ }^{8}$ Erasmo se desmarca de la hagiografía tradicional y en su Vida de san Jerónimo elimina los milagros y las manifestaciones más externas de la piedad y de la vida monacal, porque busca presentar al santo en consonancia con su manera de entender la espiritualidad, una religión interior acorde a su "filosofía de Cristo»." Así que también en esto Erasmo sería un precursor de lo que luego harán los protestantes con mayor alcance e intensidad, concretamente Georg Major con su versión depurada de las Vitae Patrum (1544). En las primeras páginas de Erasmo encontramos un dardo contra los milagros ficticios, pero también una puerta entreabierta a las ficciones si son instrumento de una piedad acorde a las enseñanzas de Cristo: ${ }^{10}$

5. Véase Wengert (2018: 51 y 56). Es un análisis actual de Las noventa y cinco tesis. Son mías, como he dicho, la búsqueda y selección de los pasajes de Lutero, como del resto de los autores, pero su pertinencia la corrobora la monografía de Riehm (2010) sobre la posición de Lutero respecto al culto a los santos.

6. Riehm (2010: 73).

7. Collins (2008: 8).

8. Chomarat (1999: 111-115 y 135-136).

9. Según Jardine (1993: cap. II), Erasmo también presenta a san Jerónimo como un precursor de sí mismo, en cuanto humanista o estudioso.

10. Riehm (2010: 46). 


\section{Eximii Doctoris Hironymi Stridonensis vita, ex ipsius potissimum literis contexta}

En efecto, existe una especie de asombrosa credulidad del vulgo; más bien, un no sé qué hondamente implantado en las mentes de los mortales, de modo que escuchan de mejor grado las cosas inventadas que las sucedidas y aprueban de mejor grado las historias inventadas más allá de la fe de la verdad que las verdaderas; hasta tal punto que, en otro tiempo, los varones sabios, cualquier cosa que querían que fuese fuertemente encomendada a la multitud, esa la celebraban con fabulosos milagros, como la religión de los dioses, los nacimientos de las ciudades o de los pueblos, los orígenes de las familias nobles, los ejemplos de clarísimos príncipes [...]. ${ }^{11}$

Yo juzgo que nada es más correcto que describir a los santos tal como ellos mismos fueron, en cuyas vidas, incluso si se descubre algún error, esto mismo se convierte en ejemplo de piedad para nosotros. Por lo demás, en caso de que alguno se deleite verdaderamente con las ficciones, si este retrata sabiamente la figura de un varón pío, cualquiera que sea su nombre, no con el saco, el cilicio, los látigos, los prodigiosos ayunos, las increíbles vigilias, sino a partir de las propias enseñanzas de Cristo, de tal modo que primero haya conocido y meditado a fondo la fuerza de la piedad cristiana y después reproduzca eficazmente su imagen, a este podría ser que lo tolerara. ${ }^{12}$

\section{0 (23 de junio) Martín Lutero A la nobleza cristiana de la nación alemana acerca del mejoramiento del estado cristiano}

Aquí Lutero ya critica el exceso de fiestas dedicadas a los santos y de canonizaciones: ${ }^{13}$

Sería menester abolir todas las fiestas, conservando sólo el domingo. [...] La causa: porque hay abuso en el beber y jugar, en el ocio y toda clase de pecados, ofendemos a Dios más en los días de fiesta que en los laborables. [...] No sólo no se presta servicio alguno a Dios, ni a los santos, sino que se les inflige grave deshonra con tantos días sagrados. Sin embargo, algunos prelados atolondrados creen haber hecho una

11. «Est quidem mira quaedam vulgi credulitas, immo nescio quid penitus insitum animis mortalium, ut ficta lubentius audiant quam gesta: et commenticiis supraque veri fidem fabulis libentius assentiantur quam veris: adeo ut olim viri prudentes quicquid vehementer commendatum esse vellent multitudini, id fabulosis miraculis celebrarent: velut numinum religionem, origines urbium aut gentium, exordia nobilium familiarum, exempla clarissimorum principum [...]».

12. «Ego nihil arbitror esse rectius, quam eiusmodi describere sanctos, cuiusmodi fuerunt ipsi, in quorum vita si quid etiam errati deprehenditur, hoc ipsum nobis vertitur in exemplum pietatis. Caeterum si quis omnino figmentis delectetur, is si prudenter effingat pii viri simulacrum, quocumque nomine, non sacco, cilicio, flagris, prodigiosis jejuniis, vigiliis non credendis, sed ex ipsis Christi decretis, sic ut primum Christianae pietatis vim penitus habeat cognitam ac perspectam, deinde scite illius exprimat imaginem, is mihi fortasse tolerabitur».

13. Collins (2008: 137-138) ofrece además el dato de que en una carta al emperador aneja a este texto Lutero condena el proceso de canonización de san Antonino de Florencia, paralelo al de san Benón, del que en este momento nada dice, aunque sí arremeterá contra la celebración de esa otra canonización cuatro años más tarde (vid. Lutero 1524). 
buena obra al instituir una fiesta para Santa Odila o para Santa Bárbara, cada cual según su ciega opinión. ${ }^{14}$

Más aún, cuando las peregrinaciones no toman incremento, se comienza a canonizar a los santos; no en honor de los mismos que sin canonización serían suficientemente venerados, sino para conseguir la concurrencia de peregrinos y obtener dinero [...]

¿Qué espíritu le dio al Papa autoridad para canonizar a los santos? ¿Quién le dice que son santos o no? [...]

Aunque la canonización de los santos hubiera sido buena en tiempos anteriores, ahora no lo es. ${ }^{15}$

\section{0 (agosto-octubre) Martín Lutero La cautividad babilónica de la Iglesia}

Y aquí reprueba ya explícitamente el culto a los santos, que considera idolatría:

aquellos discursos sobre peregrinaciones, el culto perverso de los santos, las leyendas mentirosas sobre los santos, la credulidad diversa y el ejercicio de obras y ceremonias. Con todo esto se extingue la fe en Dios y se fomenta la idolatría. ${ }^{16}$

\section{3 (junio) Johann Lonitzer \\ Catechesis de bona Dei voluntate erga quemvis Christianum, deque Sanctorum cultu \& invocatione}

Lonitzer fue un teólogo alemán protestante, estudiante y maestro en Witenberg, donde siguió a Lutero y a Melanchthon. En lo que plantea en este libro parece que Lutero habla por su boca. Sostiene que ni la Virgen ni los santos son mediadores ante Dios; solo Cristo. ${ }^{17}$ Critica la creencia en los milagros junto a los sepulcros y reliquias de los santos:

Pues bien, esta epístola en conjunto contiene que la santa Virgen y todos los santos no deben ser apreciados de otro modo que como la Escritura los aprecia: que los santos no son nuestros mediadores e intercesores, sino Cristo. ${ }^{18}$

[...]

¿Pero qué pensar de los milagros que ocurren junto a los sepulcros y reliquias de los santos? Por mi parte opino que ningún milagro sucede por los santos, o si ocurriesen,

14. Lutero (1967 [1520]: 111-112).

15. Lutero (1967 [1520]: 114-115).

16. Lutero (1967 [1520]: 229).

17. A cambio, el luteranismo sí otorgaba a la Virgen y a los santos el reconocimiento de exempla fidei o testimonios de la fe, y utilizaba sus imágenes, particularmente la de san Cristóbal, como representación de la fe (véanse Steiger 2012 y Kimmig-Völkner 2016).

18. "Continet autem epistola in universum, divam virginem et omnes sanctos, secus non commendandos atque scriptura commendat eosdem. Sanctos non esse mediatores, et intercessores nostros, sed Christum» (Lonitzer 1523: f. dv). 
se originan en un error de juicio: los corazones de los simples se ofuscan con el error de atribuirlos más a los santos que justamente al verdadero, vivo y único protector y ayudante nuestro, en quien está la vida, salud y esperanza nuestra.

Además, aunque ocurran milagros junto a los sepulcros de los mártires y santos de Dios, no suceden porque los santos lo impetran, sino porque Dios testimonia el vehemente amor hacia sus santos. ${ }^{19}$

\section{Josse van Clichtove \\ De veneratione sanctorum}

Clichtove fue un importante teólogo católico belga, profesor y Bibliotecario de La Sorbona, y autor de la Determinatio (1521) de esa universidad contra Lutero. Da la impresión de que De veneratione sanctorum, que defiende el culto a los santos y a la Virgen María, la veneración de las reliquias y las imágenes de los santos, y la narración selectiva de milagros, lo escribe como reacción sobre todo al texto de Lonitzer, dado que hasta ese momento los escritos personales de Lutero en esta materia carecían del alcance del tratado de Lonitzer. No obstante, Riehm argumenta que Lutero fija su posición teológica definitiva sobre los santos en 1523, en sus sermones y en sus disposiciones para el culto; una posición que se sintetiza en el rechazo de las supersticiones, los milagros e historias apócrifas; la denuncia de los excesos de fiestas, peregrinaciones, reliquias y canonizaciones; y la negación de la intercesión de los santos y de la ejemplaridad de sus obras. Solo admite la ejemplaridad de su fe y de su confianza en la gracia de Dios. ${ }^{20} \mathrm{~A}$ partir de aquí lo que subirá en intensidad será su tono, pero no habrá ideas nuevas. En todo caso, aunque el «hagioclasta» material a través de un tratado específico fuera Lonitzer, la inspiración provenía de Lutero, y en coherencia con esa naturaleza de movimiento colectivo más que de obra personal, Clichtove no especifica un enemigo concreto, sino que dice escribir contra los luteranos y otras herejías:
[Prólogo]
[...] y al surgir la detestable escuela de los luteranos a partir de aquellos de Wyclif y de sus afines, hemos pensado que ahora hay que desenvainar la espada literaria. Porque del triste báratro de las herejías ya en otro tiempo condenadas, claramente en esta época otra vez ha subido a las alturas esta que sostiene imprudentemente que los santos, que habitan en el cielo, no deben ser honrados por nosotros, y que

19. «Sed quod de miraculis sentiendum est, quae apud sanctorum fiunt sepulchra et reliquas? Nulla a sanctis miracula fieri equidem opinor, aut si qua fiant, a spiritu calumniante originem ducere. Quibus simplicium corda errore involvantur, ut sanctis plus tribuant quam ipsi vero, vivo et unico protectori et adiutori nostro, in quo est vita salus et spes nostra.

Praeterea etiamsi miracula apud martyrum et sanctorum dei sepulchra fiant, non fiunt, quia sancti hoc impetrant, caeterum, quia vehementem in santos suos amorem, testatur deus» (Lonitzer 1523: f. IIr).

20. Riehm (2010: 103-115, 187 y 202-203). 
no deben ser objeto de plegarias o de otro tipo de veneración religiosa por parte de los mortales. [...] Lo cual me determinó claramente a elaborar la reacción a tan execrable dogma y a mostrar la verdad contraria a sus planteamientos, con el presente opúsculo, que distribuí en dos libros. El primero de ellos prueba, a partir de las Sagradas Escrituras y de testimonios y argumentos hallados en otros lugares, que debemos honrar y rezar a los santos. El siguiente, por su parte, diluye y destruye los argumentos de quienes sostienen lo contrario y niegan que debe rendirse honor a los santos y rezarles oraciones. ${ }^{21}$

\section{Jacob van Hoogstraten \\ Dialogus de veneratione \& invocatione sanctorum, contra perfidiam lutheranam}

Hoogstraten fue un teólogo belga dominico, Inquisidor General en Colonia. Contraargumenta a Lonitzer y otras herejías antiguas. Aparece en el conocido grabado de Hans Holbein, el Joven, entre los masacrados por Lutero (figura 1).

21. «[...] et ex Viclevistarum, affiniumque illis Lutherianorum tetra prodiens officina: mucronem literarium nunc distringendum duximus. Quod plane hoc seculo: ex tristi haereseon iam olim damnatarum barathro, rursum superas emersit in auras: imprudenter astruens, non esse honorandos a nobis sanctos, regni celestis cives: neque orationibus, aliave religiosa veneratione a mortalibus colendos. [...] Quod plane me perpulit ad elaborandam tam execrandi dogmatis convulsionem: commonstrandamque, ex opposito repugnantem illi veritatem, praesente opusculo: quod in duos libros digessi. Eorum prior, ex sacris literis et aliunde petitis testimoniis atque rationibus: comprobat honorandos esse, et orandos a nobis sanctos. Posterior vero, rationes eorum qui adversas tutantur partes, abnegantque sanctis deferendos esse honores, orationesque fundendas: diluit ac dissolvit» (Clichtove 1523). 


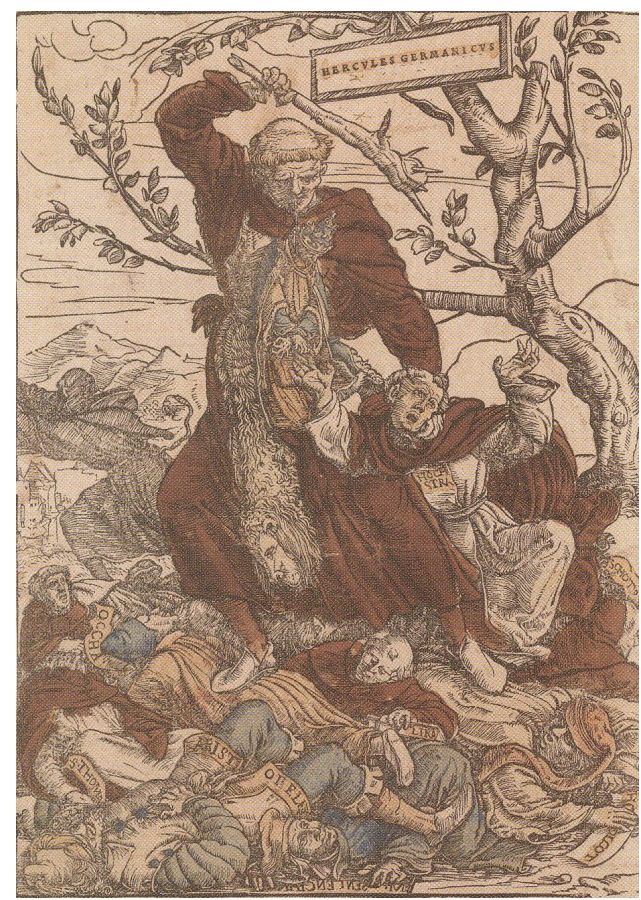

Figura 1

Grabado de Hans Holbein, el Joven, 1522. Representa a Lutero como Hércules, destruyendo la autoridad de la Iglesia papista (en vez de la hidra). A sus pies yacen Aristóteles, Tomás de Aquino, Guillermo de Ockham, Robert Holcot, Nicolás de Lira y Pedro Lombardo («Magister sententiarum»). Sujeta con su mano al inquisidor Jacob van Hoogstraten, y del cuello cuelga, ahorcado, el papa Adriano VI.

\section{Martín Lutero}

Contra el nuevo idolo y antiguo demonio que será elevado en Meissen

Es un tratado que ataca la celebración en la ciudad alemana de Meissen de la canonización de san Benón, que había sido obispo de esa sede en el siglo XI. Según Collins, ${ }^{22}$ es la primera crítica extensa del culto a los santos realizada por Lutero. Reprueba sobre todo la Vida de san Benón escrita por Jerome Emser, de modo que Lutero se posiciona aquí contra el culto y contra la hagiografía. De acuerdo con la síntesis de Collins, ${ }^{23}$ Lutero expresa que su juicio no va dirigido contra el obispo canonizado, sino contra «Satán, revestido en plata y oro, levantado y adorado bajo 
el nombre de Benón», una figura abominable creada por los papas y escritores de leyendas que distraía a los fieles del culto solo debido a Dios.

\section{Johann Eck \\ Enchiridion locorum communium adversus lutheranos}

Teólogo alemán y principal antagonista de Lutero. ${ }^{24}$ Participó en la redacción de la bula Exsurge Domine, que instaba a Lutero a que se retractase de sus errores. Eck, en dos capítulos no muy extensos de su Enchiridion, defiende la veneración a los santos por cuatro vías (Sagradas Escrituras, argumentos, patrística y tradición de la Iglesia) (cap. XIV); y la utilidad y legitimidad de las imágenes del crucifijo y de los santos (cap. xv).

\section{Martín Lutero}

A toda la clerecía reunida en Augsburgo para la dieta del año 1530

Lutero, más contundente cada vez, reprueba:

De esta abominación se han derivado todas las demás [...], las peregrinaciones, los ayunos, el culto de los santos, las reliquias. ${ }^{25}$

Además de denunciar oraciones y devociones concretas a determinados santos, Lutero incluye en la enumeración de abusos de la Iglesia de Roma:

12. Culto de santos, de los cuales algunos nunca nacieron. 13. Desmedidas fiestas de santos. [...] 16. Innumerables reliquias basadas en engańos. ${ }^{26}$

\section{Martín Lutero \\ Contra Juan Salchicha (Hans Wurst)}

Lutero sube aquí el tono hasta lo intemperante. Si ya en 1520 había identificado el culto a los santos con la idolatría, aquí llega a afirmar, con mucha más explicitud, el paganismo de la Iglesia de Roma, y hasta atribuye al papa la afirmación de que "Cristo ya no es necesario»:

Décimo, ¿quién os ha mandado erigir esta nueva idolatría: la de rendir culto a los santos, canonizarlos e instituir días festivos y de ayuno en su honor, como si fueran Dios mismo, de modo que la gente confía y busca consuelo en los méritos de ellos

24. Hay dos libros recientes que se ocupan de la controversia entre Lutero y Eck: un volumen colectivo planteado como comparación entre ambos teólogos (Bischof y Oelke 2017) y el capítulo 6 del libro de Rex (2017).

25. Lutero (1967 [1530]: 294).

26. Lutero (1967 [1530]: 319-320). 
más que en los méritos y la sangre del propio Cristo? [Un Cristo] que vosotros nos habéis presentado como un juez, a quien debíamos apaciguar y cuya gracia debíamos alcanzar por medio del mérito y la intercesión de su madre y de todos los santos, así como por nuestro culto a los santos. Como resultado, en este aspecto, vuestra iglesia se ha convertido en una mera iglesia pagana, en la que se venera a Júpiter, Juno, Venus, Diana y a otros hombres muertos. ${ }^{27}$

Y ahí está el testimonio de san Pedro, en Hch. 4: "No hay dado ningún otro nombre por el que se pueda ser salvo más que el de Jesucristo». Contra esto, el papa Heinz de Roma dice: ${ }^{28}$ "¡De ningún modo! Sí que hay muchos otros nombres mediante los cuales la gente puede salvarse, particularmente mi nombrey, a continuación, todo los que yo diga: san Francisco, santo Domingo y todas aquellas obras que como tales me proporcionen dinero y hagan que reyes y emperadores se postren a mis pies. Aquí está la santidad y la salvación, Cristo ya no es necesario ni de utilidad», etc. ${ }^{29}$

\section{Georg Witzel Hagiologium seu de sanctis Ecclesiae}

Collins incluye esta obra en lo que denomina «hagiografía polémica», ${ }^{30}$ aunque con ese adjetivo parece referirse más bien al contexto de la controversia sobre el culto a los santos y la hagiografía que al mismo texto, pues según él, Witzel, que había abandonado el sacerdocio católico para seguir a Lutero y después había vuelto al catolicismo, buscaba una reconciliación entre cristianos, y pensaba que el género hagiográfico, de larga tradición, podía ser un instrumento para ella. Por eso evita atacar a los protestantes y reduce la narración de milagros, al tiempo que enaltece la piedad, buscando el acercamiento.

\section{Georg Major, con prólogo de Martín Lutero}

Al final de su vida Lutero se percata de que la tradición hagiográfica es un recurso del que el protestantismo también puede sacar partido, y, en sentido contrario a su anterior condena de las vidas de santos, promueve ahora compendios hagiográficos, para que teólogos de su ámbito extraigan de las Vitae patrum en este caso y de las vidas de santos en el de Spalatin la materia acorde a su doctrina. ${ }^{31}$ Piotr J. Malysz observa que Lutero y sus colegas llegaron a ver las vidas de santos como un repositorio de pruebas de la apostasía del papa, también de evidencias de que la doctrina protestante no era nueva, y finalmente como muestras de piedad. ${ }^{32}$ Dado que Lutero impulsa ambas recopilaciones, con un compromiso que queda fijado

27. Lutero (2016 [1541]: posición en Kindle 784-788).

28. Identifica al papa con Heinz von Wolfenbüttel o duque Enrique II de Braunschwieg, enemigo de los luteranos en los conflictos armados de la Reforma (Tomás 2016: posición en Kindle 143-210).

29. Lutero (2016 [1541]: posición en Kindle 990-994).

30. Collins (2008: 131-132).

31. Riehm (2010: 178-180).

32. Malysz (2009). 
en sus propios prólogos a ambas obras y en los prefacios de Major y de Spalatin, podría decirse que Lutero vira de hagioclasta a hagiógrafo, aunque sea por vía vicaria, sin que ello implique un cambio en su posición teológica respecto a los santos, que llevaba veinte años fijada, según hemos visto.

\section{Vitae Patrum, in usum ministrorum verbi, quoad eius fieri potuit repurgatae}

Major estudió en Witenberg, donde tuvo como maestros a Lutero y a Melanchthon, y en Witenberg fue profesor de la Facultad de Teología, predicador, traductor y editor, además de participar activamente en la política religiosa y eclesiástica. ${ }^{33} \mathrm{El}$ destinatario directo de este libro no es el gran público, sino los predicadores, tal como indica el título de la obra, que traducido dice Vidas de los Padres, para el uso de los ministros de la palabra, en la medida en que pudieron ser purgadas, aunque también es cierto que su contenido llegaría a los fieles de forma indirecta. En todo caso, restringir en el título el círculo de lectores revela prevención contra el género. Además, el material original está purgado de las «f́́bulas estúpidas y mentiras impías», que según Lutero y Major, ocasionan la burla de los milagros. ${ }^{34}$ Así que la manipulación protestante de la hagiografía consiste en un cherry picking o selección interesada de los dichos y hechos de las Vitae Patrum acordes a la doctrina evangélica de Lutero, y exclusión consciente de los dichos y hechos adversos a sus planteamientos, por ejemplo de la vida monástica y de toda expresión contraria a su idea de la justificación. ${ }^{35}$ Recordemos que también en la eliminación de milagros y manifestaciones externas de la piedad y de la vida monacal Erasmo había sentado un precedente en su Vida de san Jerónimo (1519). A ojos de los teólogos católicos la manipulación protestante será una nueva blasfemia y un ultraje contra la tradición hagiográfica (vid. los textos de Lippomano y Surio, y la carta de Pío V a Surio):

\section{[Prólogo de Lutero]:}

Entre otras obras de la furia de Satán esta no es la menor: que las historias, o como las llaman Leyendas de los santos, haya destruido en su mayoría, y las que haya sufrido que subsistan (sin duda contra su voluntad), haya corrompido con fábulas estúpidas y mentiras impías, de manera que algunas fábulas se parezcan más a la verdad y sean más útiles a la gente. ${ }^{36}$

$[\ldots]$

33. Todas estas facetas son atendidas en un volumen colectivo (Dingel y Wartenberg 2005).

34. Sin embargo, Backus (2008: XVI) afirma que aunque Major invoque las Vitae Patrum de san Jerónimo (siguiendo la muy asentada atribución falsa) como fuente de las suyas, también utiliza la Legenda aurea de Vorágine.

35. Vid. Malysz (2009).

36. «Inter cetera Satanici furoris opera hoc non minimum est, quod historias, seu quas vocant, Legendas Sanctorum, quam plurimas aboleverit, et quas extare passus est, (haud dubie non volens) ita corruperit fabulis stultis et impiis mendaciis, ut veri multo sint similiores et utiliores gentium quaedam fabulae». 
Porque si se atrevió a contaminar a Roma tan espantosamente, [...] ¿qué, pregunto, en otras partes del mundo [...]? A partir de esto, el mundo está lleno de impiedad, idolatría, cultos, fábulas y leyendas de santos, misas profanas, ¿y quién enumeraría todos los escándalos? Ve la misma Escritura y sacramentos de Dios, ¿con cuántos géneros y especies de herejías y de errores intentó causar la ruina total? Y hoy en esto su furia no es menor que en los tiempos anteriores. Esta malicia también atacó sobre todo este libro celebérrimo, que todo el orbe de la Iglesia llama Vidas de los padres. ${ }^{37}$

[...]

Con estas palabras parece que san Jerónimo se refiere a este libro, y que claramente como con el dedo lo muestra. Si en aquel tiempo este libro fue corrompido y confundido, ¿`cuáles y cuántas fábulas y mentiras piensas que hayan llegado después? Cuales son las de Marino, Eufrosina, Simón sobre la columna, y muchas similares, que en parte son poéticas, [...] en parte ficciones totalmente impúdicas, por las cuales la Iglesia es objeto de burla en sus milagros verdaderos. ${ }^{38}$

[...]

para que este libro de las Vidas de los padres sea censurado con mayor severidad, puesto que toda la materia lícita fue confundida con lo impío con perverso furor, para que no sepas qué es de Rufino, qué de Jerónimo o de otros, después, de las que ciertamente son de Jerónimo, con qué inspiración las hubiese escrito, impulsé y apenas rogué a D. Georg Major que recibiera este peso, sin duda molestísimo, de elegir y purgar todo. En efecto están en este libro, como también en Jerónimo, muchos dichos egregios y hechos, que es necesario reunir como fragmentos de la mesa evangélica y no desechar con estas impurezas que algunos imprudentes mezclaron. ${ }^{39}$

\section{[Prólogo de Major]:}

En su propio prólogo Major se hace eco de la idea de que las fábulas de la tradición hagiográfica llaman a la burla de la religión cristiana. También cabe

37. "Quod si Romam ausus est tam fede conspurcare, [...] quid rogo in aliis partibus orbis [...]? Hinc mundus plenus est impietate, idolatria, cultibus, fabulis et legendis sanctorum, missis prophanis, et quis omnia scandala numeret? Ipsam vide scripturam et Sacramenta Dei, quot generibus et speciebus haeresium et errorum tentavit prorsus perdere? Nec hodie in hac re minus furit quam antea semper. Ea malitia quoque imprimis appetivit hunc Librum celeberrimum, quem Vitas patrum appellat orbis totus Ecclesiae».

38. «His verbis videtur S. Hieronymus hunc librum nominare, et plane velut digito monstrare. Qui si tempore illo sic fuit corruptus et confusus Liber, quid et quantum putas post illa tempora accesserit fabularum et mendatiorum? Qualia illa sunt de Marino, Euphrosyna, Simone super columna, et similia multa, quae partim poetica sunt, [...] partim prorsus impudentissima figmenta, quibus irrisa est Ecclesia in suis veris miraculis».

39. «ut liber iste Vitas patrum opus habeat severiore censura, postquam sunt omnia fanda, nefanda malo permixta furore, ut nescias, quae Ruffini, quae Hieronymi vel aliorum, deinde quae Hieronymi certa sunt, quo spiritu haec vel illa scripserit, impuli et vix perpuli precibus D. Georgium Maiorem, ut hoc onus seligendi et purgandi omnia susciperet, haud dubie molestissimum. Sunt enim in eo Libro, ut et in Hieronymo, multa egregie dicta et facta, quae ut fragmenta Evangelicae mensae colligere oportet et non abiicere cum istis sordibus, quas alii imprudentes miscuerunt». 
destacar que afirma que el propio Lutero en sus sermones a veces cuenta alguna de las historias de las Vitae Patrum, seguramente porque, como dice antes en consonancia con Lutero, en ellas se pueden encontrar dichos y ejemplos provechosos para la fe del buen cristiano:

¿Luego por qué las titularon "vidas", cuando no narran la doctrina, los cargos de la vocación, los conflictos, que en la vida de los grandes varones en la Iglesia deben observarse principalmente, sino las ceremonias domésticas? Sin embargo, por más que la historia sea pobre, no es inútil en cambio que subsista. Aprovecha en efecto a los píos y a los instruidos rectamante en la doctrina cristiana contemplar cuán fácilmente las mentes humanas caen de la pureza evangélica a las ceremonias. ${ }^{40}$ [...]

Por consiguiente, quienes lean esta historia, estén antes prevenidos con el conocimiento del Evangelio, y extraigan recto y pío juicio de todas las partes de la vida cristiana, vean cuáles concuerdan con la fe, y cuáles, por el contrario, son supersticiosas. Sin embargo alguna vez se ofrecen como dichos y ejemplos que pueden aprovechar al prudente y pío lector. Pero como estos libros permaneciesen antes confusamente editados, y por todas partes fuese evidente que las fábulas, que parecen inventadas para mofarse de la religión cristiana, habían sido insertadas por impostores, el clarísimo y reverendo varón D. Doctor Martín Lutero, a quien amo $\mathrm{y}$ venero como a un padre, por los ingentes beneficios públicos y privados, puesto que, hablando como suele en los sermones familiares de todos los tiempos de la Iglesia, alguna vez también cuenta alguna de estas historias, me encargó este cometido: que examinase este libro, y donde hubiese fábulas de vanidad manifiesta, las suprimiese. No pensé que pudiera estar en desacuerdo con su voluntad. Habiendo releído esta historia, seleccioné las narraciones, para que puedan leerse sin embarazo. Pero para que no pareciera que yo haya usado una censura demasiado severa en un libro ajeno, menor la ejercí que la deseada por un lector más severo, y pido que mi labor examinen los buenos estudiosos. ${ }^{41}$

40. «Deinde cur Vitas inscripserunt, cum non doctrinam, non vocationis officia, non certamina narrent, quae sunt in vita magnorum virorum in Ecclesia precipue spectanda, sed domesticas ceremonias? Quanquam autem tenuis historia est, tamen extare eam non est inutile. Prodest enim piis et recte institutis in doctrina Christiana videre, quam facile a puritate Evangelii, ad ceremonias humanae mentes delabantur».

41. "Qui igitur hanc historiam legent, sint antea premuniti Evangelii cognitione, et adferant rectum et pium iudicium de omnibus partibus vitae Christianae, videant quae sint Analoga fidei, quae econtra sint supersticiosa. Interdum autem offerunt se dicta aut exempla quae prudenti et pio Lectori prodesse possunt. Cum autem extarent antea hi Libelli, confuse editi, et adpareret passim ab impostoribus insertas esse fabellas quae ad deridendam Christianam professionem confictae videntur, vir clarissimus ac reverendus D. Doctor Martinus Lutherus, quem et propter publica, et propter privata beneficia ingentia, tanquam patrem et amo et veneror, cum in familiaribus sermonibus de omnibus Ecclesiae temporibus loquens, ut solet, interdum etiam aliquid ex his historiis recitet, mihi hoc negotium dedit, ut hunc Librum recognoscerem, et fabellas alicubi quarum manifesta est vanitas delerem. Huius voluntati non duxi repugnandum esse. Relecta hac historia, distinxi narrationes, ut expeditius legi possint. Ne vero in alieno Libro nimis severe uti censura viderer, pauciora sustuli quam velit Lector severior, ac peto ut laborem meum studiosi boni consulant». 


\title{
1544 Georg Spalatin, con prólogo de Martín Lutero Magnifice consolatoria exempla et sententiae, ex vitis et passionibus sanctorum et aliorum summorum virorum, brevissime collectae, opera
}

\section{Spalatin fue teólogo, y secretario y asesor de Federico III de Sajonia. Intervino} ante él en favor de Lutero. ${ }^{42}$ Presenta así su obra:

\begin{abstract}
Al lector: este libro es breve, pero su consuelo es mucho. Léelo, pues el lector recibirá muchos beneficios. ${ }^{43}$

[Prólogo de Lutero]:

Reuniste los dichos y hechos más puros de los santos de Dios. En efecto estos son pertinentes no solo para cerrar la boca de quienes dicen iniquidades contra nosotros, y de los que nos denigran como si sembráramos nuevas herejías o, cuando quieren parecer que hablan con más moderación, nuevas opiniones y dogmas, sino también en verdad para confirmar nuestras conciencias instruidas, con una nube tan numerosa de testimonios y ejemplos de los antiguos, que con nosotros las mismas ideas percibieron, dijeron, hicieron y mostraron. ${ }^{44}$

[...]

Callo las mentiras que hay en sus historias, sembradas por impíos ministros del diablo; sin embargo, en lo que toca a la resistencia y al testimonio, vemos con cuánta pureza y constancia atestiguan su fe. ${ }^{45}$

[Prólogo de Spalatin]:

Ejemplos muy selectos y sentencias de máximo consuelo de los mártires y de otros santos [...] encubiertos por milagros en su mayor parte falsísimos, de tal manera que pasan inadvertidos hasta al lector medianamente atento, o más bien incluso son absolutamente desdeñados por la mayoría como cosas sin importancia y muy triviales, por culpa de los milagros, como puede verse en casi todas las así llamadas Leyendas y en sus escritores, con poquísimas excepciones. Ya solo por esto es evidente que tales escritores hicieron esto más para retener al pueblo en la idolatría. ${ }^{46}$
\end{abstract}

42. Esta cuestión y otras de su biografía referidas a su apoyo a la Reforma, son abordadas en los libros de Burkert y Röhlin (2015) y Kessler (2017).

43. «Ad lectorem: Est brevis hicce liber, sed consolatio multa. Perlege, lectori commoda multa dabit».

44. "collegisti Sanctorum Dei dicta et facta puriora. Pertinent enim haec ipsa non solum ad obstruendum os loquentium iniqua contra nos, et obtrectantium nobis, quasi novas haereses vel ubi mitius volunt loqui videri, novas opiniones et dogmata seramus, Verum etiam ad confirmandas nostras conscientias, tot testimoniorum et exemplorum Veterum nube, eruditas, qui eadem nobiscum senserunt, dixerunt, fecerunt et tulerunt». Esta cita en concreto está traducida por Riehm (2010: 179) al alemán.

45. "Taceo mendacia, quae sunt in eorum Historias, per impios Diaboli ministros seminata, Tamen cum ventum est ad agonem et confessionem, videmus, quam pure et constanter fidem suam testentur».

46. «Exempla selectiora et maxime consolatorias sententias martyrum et aliorum sanctorum $[\ldots]$ miraculis plerumque mendacissimis oppressa, ut vel mediocriter diligentem fallant Lectorem immo a plerisque tanquam minama ${ }^{\text {sic }}$ et abiectissima prae miraculis prorsus praeterita etiam, ut fere in omnibus ut vocant Legendis et earum Scriptoribus, paucissimis exceptis, videre licet, Ex quo vel solo perspicuum est a talibus Scriptoribus hoc magis actum esse, ut populum in idolatria retinerent». 


\section{Martín Lutero \\ Contra el papado de Roma, fundado por el diablo}

Lutero alcanza su furor máximo en este texto y en Imagen del papado, un opúsculo satírico impreso el mismo año con versos suyos e ilustraciones de su amigo y colaborador el artista Lucas Cranach, el Viejo, a partir de bosquejos suyos. ${ }^{47}$ Ambas obras se complementan como propaganda antipapal. ${ }^{48}$ En Contra el papado de Roma, fundado por el diablo Lutero afirma que la Iglesia del papa (visto como asno) es una inspiración del diablo para sembrar «mentiras, blasfemias e idolatrías»:

[Niega la autenticidad de las cabezas de Pedro y Pablo que se muestran en Roma, y de la "Verónica»] En eso consiste, en definitiva, el mostrar y el ver la «Verónica», y hay en ello gran fervor religioso y muchas indulgencias para tan burdas mentiras. Es tanto y tan grande el placer que el condenado papa-asno y su maldita escuela de bribones en Roma [sienten] al mofarse, burlarse y reírse de los pobres cristianos (en efecto, al blasfemar contra Dios en el cielo e introducir estas idolatrías en su santa Iglesia, se ríe por lo bajines, ya que así puede ver esas blasfemas e idolátricas mentiras suyas veneradas, y gracias a ello roba y hurta los bienes y la obediencia de todo el mundo), que uno no puede evitar caer en la cuenta de que el papado, tal como se dijo más arriba, es una fantasmagoría mendaz, introducida en la Iglesia por el diablo al objeto de no hacer otra cosa que instaurar mentiras, blasfemias e idolatrías con las que echar a perder la fe y la Palabra de Dios y, por ende, afanar todo lo que tiene y posee el mundo que está bajo su poder y llevar todas las almas al diablo. ${ }^{49}$

«El que no ayune y santifique a los santos, que yo he establecido, comete pecado mortal y una desobediencia condenable. La razón: tengo el poder para atar y desatar. Es más, tal vez incluso: el que no adore mi pedo, está en pecado mortal y es merecedor del infierno, puesto que no reconoce que yo tenga el poder para atar y mandar cualquier cosa. El que no me bese los pies y, si así yo lo atare, no quiera besarme el culo, está en pecado mortal e irá al infierno profundo, ya que Cristo me dio las llaves y el poder para atar absolutamente todo»..$^{50}$

Por su parte Cranach reutiliza un grabado de 1523 para representar al papaasno (Papstesel), pero ahora acentúa sus rasgos femeninos para reflejar mejor los insultos que Lutero lanza al papa Pablo III en su obra («papisa Paula», «santa Paula», etc.): ${ }^{51}$

47. Tomás (2014: posición en Kindle 427-525).

48. El ámbito de Lutero (la idea probablemente suya, los textos de Melanchthon y Schwertfeger) y Cranach ya habían colaborado contra el papado en el temprano Passional Christi und Antichristi (1521), que contrasta la humildad de Jesús con la soberbia y boato del pontífice (Tomás 2014: posición en Kindle 432). Sobre este opúsculo hay un libro reciente de Dykema (2017), que estudia sus singularidades y analiza el uso propagandístico de las imágenes de Cristo tomadas de la tradición de los impresos devocionales alemanes.

49. Lutero (2014 [1545]: posición en Kindle 1793-1804).

50. Lutero (2014 [1545]: posición en Kindle 2070-2074).

51. Tomás (2014: posición en Kindle 468). 


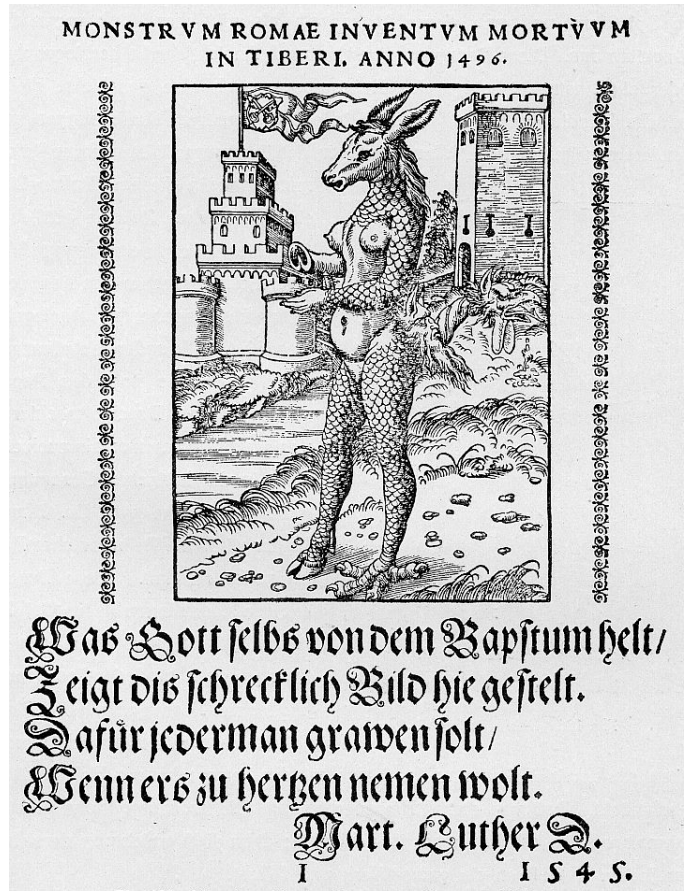

Figura 2

Lutero y Cranach, el Viejo, Imagen del papado, 1545

«Monstruo de Roma hallado muerto en el Tíber. Año 1496

Todo lo que Dios mismo piensa del papado

lo muestra este horrible retrato aquí presentado.

Por eso, terror sentiría cualquiera,

si es que seriamente tomárselo quisiera. Martín Lutero Dr.». ${ }^{52}$

Lutero, en Contra el papado de Roma, fundado por el diablo, vira hacia el exceso escatológico, pues hace decir al papa: «El que no adore mi pedo, está en pecado mortal y es merecedor del infierno", lo mismo que quien "no quiera besarme el culo». En correspondencia con ese tono, el grabado de Cranach muestra al papa Pablo III en su cátedra, entre dos cardenales (Otto Truchsess von Waldburg — barbado—, y Alberto de Brandeburgo), que sostiene una

52. "Monstrum Romæ inventum mortuum in Tiberi. Anno 1496. Was Gott selbs von dem Bapstum hellt / Zeigt dis schrecklich bild hie gestellt: / Dafuer jederman grawen sollt: / Wenn ers zu hertzen nemen wollt. Martin Luther D». Las traducciones de los textos que acompañan las imágenes y la identificación de los personajes están tomadas de Gabriel Tomás (2014: posición en Kindle 427-525). 


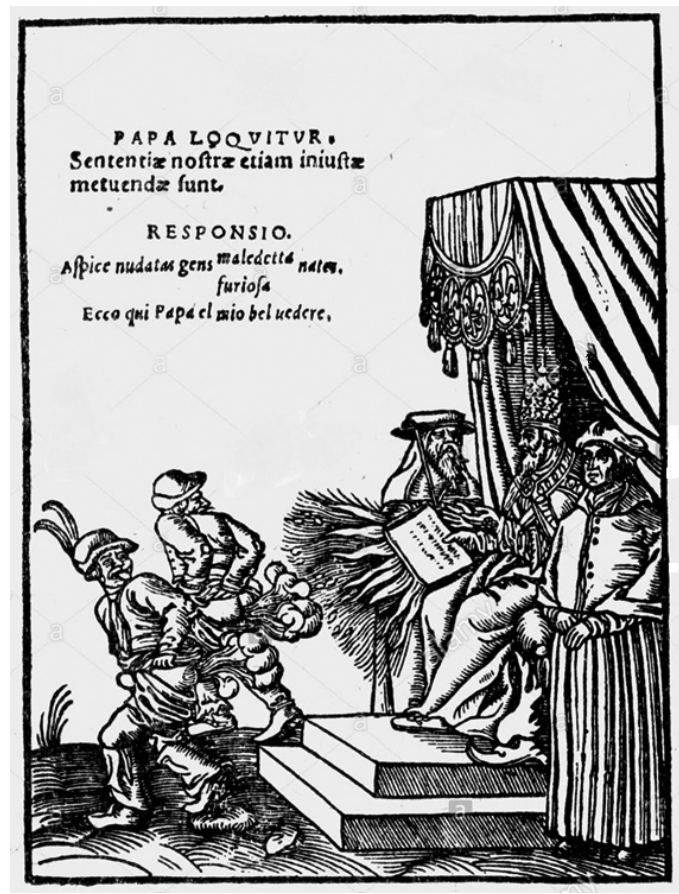

Figura 3

Lutero y Cranach, el Viejo, Imagen del papado, 1545

«Dice el papa:

Nuestras sentencias, además de injustas, hay que temerlas.

Respuesta:

¡Mirad, malditos locos, mis posaderas desnudas!

Papa, he aquí mi Belvedere».

bula de la que salen llamaradas. ${ }^{53}$ Dos hombres le dan la espalda, le muestran sus traseros y ventosean, al tiempo que uno de ellos se burla sancándole la lengua.

Contra el papado de Roma, fundado por el diablo llega a la violencia cuando Lutero escribe: «y a continuación deberían prenderlos al papa, a los cárdenales [...] y (por blasfemos) extraerles las lenguas por detrás del pescuezo y clavarlos en fila en el patíbulo». Es justo lo que dibuja Cranach:

53. Esa bula recuerda las del papa León X: la de 1520 (Exsurge Domine) en que se exigía a Lutero la retractación de sus errores, o ya la de excomunión de Lutero de 1521. Otro verso que acompaña a la ilustración, pero que no se muestra aquí, dice «No papa, que tu anatema no nos impresiona» (Tomás 2014: posición en Kindle 2843). 


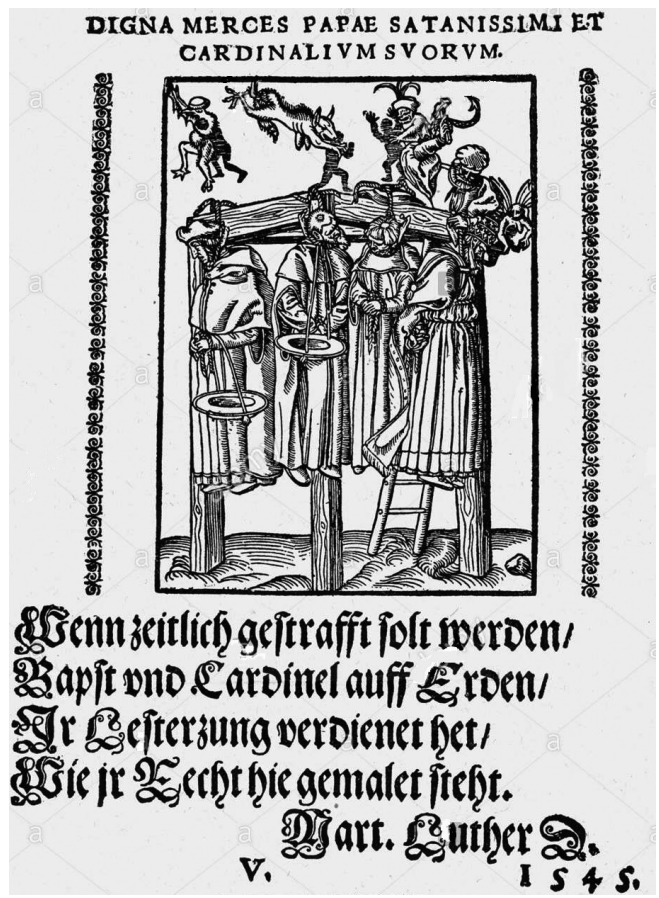

Figura 4

Lutero y Cranach, el Viejo, Imagen del papado, 1545

«La digna recompensa del satanísimo papa y de sus cardenales.

Si en la tierra, papa y cardenales, sufrir debierais castigos temporales, merecería la viperina lengua vuestra acabar como esta pintura os muestra. Martín Lutero Dr.». ${ }^{54}$

\section{1: Luis Lippomano}

Sanctorum priscorum patrum vitae, numero centum sexagintatres, per gravissimos et probatissimos auctores conscriptae

Lippomano, obispo de Verona, participó en el Concilio de Trento. Así que no es casulidad que sea autor de esta primera gran entrega de la hagiografía contrarreformista (que luego sigue Lorenzo Surio), ni que comience con una diatriba contra los luteranos. Tampoco es casualidad que comente que si hubiese incluido las vidas de santos apócrifas, anónimas o de autores de poco crédito, los

54. «Wenn zeitlich gestrafft solt werden: / Bapst und Cardinel auff Erden. / Jr lesterzung verdienet hett / Wie jr recht hie gemalet steht. Martin Luther D». 
«herejes» se habrían reído mucho. Es en este aspecto en el que más nítidamente se percibe el impacto de la Reforma sobre las vidas de santos, en el hecho de que los hagiógrafos asuman la necesidad de depurar lo apócrifo y atenerse únicamente a los autores de crédito. He tenido ocasión de comparar los prólogos de los flores sanctorum castellanos anteriores y posteriores a Trento, y el cambio tras la ruptura protestante es que si el anónimo fraile jerónimo autor del flos sanctorum de 1516 se conforma con avisar de lo dudoso de los pasajes apócrifos, que sin embargo incluye (como ya hacía el propio Vorágine en el siglo XIII), por el contrario Villegas y Ribadeneira declaran en sus prefacios su propósito de eliminar lo apócrifo y de valerse únicamente de fuentes autorizadas (Baños 2018: 35-40). No obstante, debe entenderse, a este respecto, que la crítica a la hagiografía más milagrera, fabulosa y supersticiosa no es un planteamiento exclusivo de los protestantes, ni siquiera de reformadores católicos, como Erasmo, sino que la comparten teólogos tan ortodoxos como Melchor Cano. ${ }^{55}$

Dedicatoria de Lippomano al obispo de Calahorra, Juan Bernardo Díaz de Lugo:

Hace más de treinta años, reverendísimo prelado, que la herejía luterana, acaso la más cruel de todas las que hasta ahora brotaron, devasta allí la Iglesia Católica. ${ }^{56}$ $[\ldots]$

Por tanto, aunque la pestilentísima herejía se halle ya bastante abatida y hollada por los testimonios de las Escrituras y de los santos padres, pensé que haría algo que vale la pena si, por medio de los egregios hechos y ejemplos de los santos varones (lo que ellos acaso hicieron más sobriamente), extinguiera completamente y ahogara el resto del infaustísimo hálito que parece que todavía subsiste y palpita en ella, y, como mortífero vivero, lo extirpara tan radicalmente del campo de la Iglesia que de ninguna manera pudieran rebrotar. Así pues, decidí reunir en un volumen las vidas de los santos padres antiguos que florecieron desde los orígenes de la Iglesia naciente hasta el tiempo de D. Bernardo Abad, al cual en la actualidad situamos en medio entre los antiguos y más recientes padres, escritas por varones sin duda eruditos y aprobados, en las cuales se encuentran hasta tal punto degolladas y apuñaladas todas las blasfemias y desatinos de estos malvados, que, a no ser que alguno quisiera por su propia iniciativa ser desvergonzado, y palpar las tinieblas al mediodía, y consciente (como dicen) y sabedor precipitarse en el profundo infierno, no puede ya más engañarse ni enredarse con ellos. ${ }^{57}$

55. Arronis (2017: 283-285).

56. "Triginta et eo amplius anni sunt Reverendissime Praesul, quod Lutherana haeresis omnium forte quae hucusque viguerunt saevissima, catholicam devastat Ecclesiam».

57. "Cum ergo pestilentissima haeresis satis scripturarum et sanctorum patrum testimoniis iam prostrata et conculcata reperiatur. Opereprecium me facturum sum arbitratus, si sanctorum virorum egregie factis et exemplis quod illi forsan parcius fecerunt quod reliquum in ea miserrimi adhuc spiritus superesse et palpitare videtur, nunc penitus extinguerem et suffocarem, ac veluti laetifera plantaria, ita radicitus de agro Ecclesiae extirparem, ut nullatenus repullulare valerent. Decrevi itaque, sanctorum patrum antiquorum vitas, qui a primordiis nascentis Ecclesiae usque ad D. Bernardi Abbatis tempora, quem inter antiquos et recentiores patres, medium ad praesens ponimus floruerunt, ab eruditis quidem et approbatis viris conscriptas, in unum volumen redi- 
[...]

Pero una cosa es hablar en las reuniones de la iglesia a los fieles, o dirigir escritos a los varones católicos, lo cual hicieron ellos, otra luchar con los herejes mano a mano, y refutarlos en este género de escritos, lo cual ahora intentamos hacer. [...]. En efecto, quienes escribieron estas vidas que ahora divulgamos son escritores ilustres aprobados por todos, y bien dignísimos de fe (incluso para los mismos herejes, testigos a su pesar, contra los cuales principalmente se editan). Por lo demás, todo lo apócrifo (como dijimos), es decir, las vidas de estos cuyos redactores se ignoran totalmente o, si se conocen, son de pobre estimación y autoridad en la Iglesia, con escrúpulo conmemoramos, ${ }^{58}$ porque no contribuyen a probar la verdad de los dogmas, como la que nos esforzamos ahora en probar frente a los nuevos herejes, los cuales, si las hubiésemos introducido, al instante sacudirían la cabeza, arrugarían la nariz, lanzarían grandes carcajadas y dirían: "Que la fe de estos vaya sobre el crédito de esos mismos autores». ${ }^{59}$

\section{Concilio de Trento (1545-1563) \\ Sesión XXV, de 3 y 4 de diciembre de 1563: "De la invocación, veneración y reliquias de los santos y de las sagradas imágenes"}

Como era de esperar, el Concilio de Trento reafirma el culto a los santos, la veneración de las reliquias y la ejemplaridad de los relatos hagiográficos:

Manda el santo Concilio a todos los obispos y demás personas que tienen el cargo y obligación de enseñar, que instruyan con exactitud a los fieles ante todas cosas, sobre la intercesión e invocación de los santos, honor de las reliquias y uso legítimo de las imágenes, según la costumbre de la Iglesia Católica y Apostólica, recibida desde los tiempos primitivos de la religión cristiana, y según el consentimiento de los santos padres y los decretos de los sagrados concilios, enseñándoles que los santos reynan juntamente con Cristo, ruegan a Dios por los hombres, que es bueno y útil invocarles humilmente y recurrir a sus oraciones, intercesión y auxilio para alcanzar de Dios los beneficios por Jesucristo su hijo, nuestro Seńor, que es solo nuestro redentor y salvador; y que piensan impíamente los que niegan que se deben invocar los santos que gozan en el Cielo de eterna felicidad; o los que afirman que los san-

gere, in quibus improborum istorum blasphemiae omnes et delyramenta ita jugulata et confossa reperiuntur, ut nisi quis ultro protervire, et tenebras in meridie palpare, ac prudens (ut dicunt) et sciens in inferni profundum praecipitari voluerit, his ulterius decipi et implicari nequeat».

58. Es esta una frase singularmente oscura, pues el verbo afirmativo canimus parece contradecir la exclusión, por otro lado clara, de lo apócrifo.

59. «Sed aliud est concionibus in Ecclesia ad populum fidelem loqui, vel ad catholicos viros scripta dirigere, quod fecerunt illi, aliud cum haereticis pugnare cominus, eosque hoc scriptorum genere convincere, quod nos modo facere intendimus. [...]. Nam qui has quas nunc evulgamus vitas conscripserunt (vel ipsis haereticis invitis contra quos praecipue eduntur testibus) scriptores sunt illustres omnibus probati, et fide longe dignissimi. Caeterum apocrypha omnia (ut diximus) hoc est eorum vitas quarum scriptores penitus ignorantur, aut si sciuntur, pertenuis in ecclesia aestimationis et auctori[ta] tis sunt, diligenter canimus, neque enim ad dogmatum veritatem astruendam, qualem nunc contra neotericos haereticos astruere satagimus faciunt, qui statim si ista ingessissemus, caput contorquerent, nares contraherent, cachinnos ore profunderent, et dicerent, fides horum sit penes au[c] tores ipsos». 
tos no ruegan por los hombres; o que es idolatría invocarles para que rueguen por nosotros [...] o que repugna a la palabra de Dios y se opone al honor de Jesucristo (Tim.1,1), único mediador entre Dios y los hombres; o que es necedad suplicar verbal o mentalmente a los que reynan en el Cielo.

[...] de suerte que deben ser absolutamente condenados [...] los que afirman que no se deben honrar ni venerar las reliquias de los santos; o que es en vano la adoración que estas y otros monumentos sagrados reciben de los fieles; y que son inútiles las frecuentes visitas a las capillas dedicadas a los santos con el fin de alcanzar su socorro. [...].

Enseñen con esmero los obispos [...] saludables ejemplos de los santos y los milagros que Dios ha obrado por ellos, y arreglen su vida y costumbres a los ejemplos de los mismos santos, así como que se exciten a adorar y amar a Dios, y practicar la piedad. [...] Destiérrese absolutamente toda superstición en la invocación de los santos, en la veneración de las reliquias y en el sagrado uso de las imágenes, ahuyéntese toda ganancia sórdida; evítese en fin toda torpeza; [...]. Tampoco se han de admitir nuevos milagros, ni adoptar nuevas reliquias, a no reconocer y aprobarlas el mismo Obispo. ${ }^{60}$

\section{Lorenzo Surio De probatis sanctorum historiis}

Surio es para Collins exponente de la «hagiografía crítica», ${ }^{61}$ la que trata de editar los textos más autorizados y mejor documentados, como harán después los bolandistas. No obstante, al decir de Collins, Surio no siempre es coherente con ese planteamiento. Cabe destacar que se convirtió del protestantismo al catolicismo en Colonia, en lo que intervino Pedro Canisio, según relata este, y profesó como cartujo en la misma ciudad. Jonathan E. Greenwood muestra que Surio se considera un continuador de Lippomano, pero pretende mejorar la organización del santoral, entre otras cosas tomando como referencia el Breviario Romano promulgado por Pío V. También en esta fijación del Breviario Romano como referente canónico del elenco de santos, Surio marca la pauta a Villegas, al que luego seguirá Ribadeneira. ${ }^{62}$ Como dice Collins, la actitud de Surio no es tan irenista como la de Witzel, sino que reafirma la posición católica, en abierta confrontación con los protestantes, por ejemplo en recuperar la narración de milagros. Surio declara un criterio restrictivo en la compilación, que se atiene a fuentes fidedignas, aunque con cierta flexibilidad, mayor que la de Lippomano, y la presenta como una defensa contra la herejía protestante, lo cual confirma y autoriza nada menos que el papa Pío V. Así que podría afirmarse que Surio

60. Concilio de Trento (1847 [1563]: 328-333). Ditchfield (2007) ofrece una síntesis de las características del culto a los santos después de Trento.

61. Collins (2008: 133-134).

62. Greenwood (2018: 191-192 y 194). De este modo tanto Villegas como Ribadeneira se alinean con el planteamiento universal tridentino que parte de Lippomano y Surio (véase Guillauseau 2014). 
escribió el santoral más canónico de la Contrarreforma, que se convirtió en la compilación de referencia, por ejemplo para Villegas y Ribadeneira.

\section{[Dedicatoria de Surio al papa Pío V]:}

Aunque no obstante casi desde el principio había decidido, a ejemplo de Luis [Lippomano] en relación a todos los volúmenes sobre los santos que, Dios mediante, editaremos, reunir solamente las historias que tuvieran autores ciertos y probados, sin embargo cuando llegó el momento cambié el criterio, y admití algunas cuyos autores no pude encontrar; pero no cualesquiera, sino por una parte las que tengan testimonio grave en los vetustísimos martirologios, y por otra parte escritas de tal manera que por sí mismas inspiren confianza al lector prudente, y muestren suficientemente estar escritas de buena fe; aunque puede que o por incuria de los copistas, o por voluntad de quienes las escribieron, o por algún otro caso los nombres de los autores fueron omitidos. Entretanto, sin embargo, fui más restrictivo en incluir este tipo de historias; de hecho verdaderamente omití muchas que pareciesen compuestas poco gravemente y no suficientemente para la fe. En efecto, no quise proporcionar a los impíos herejes ocasión para la calumnia, pero no dudo, dada su desvergüenza, que fácilmente encontrarán qué denigrar también en estas historias que tienen autores ciertos y graves. Estas ciertamente constituyen la mayor parte de esta obra. Así en efecto aquellos incluso a Pablo y a Hilarión, cuyas vidas escribió el beatísimo Jerónimo, por una parte quitan credibilidad, por otra acusan de crimen de homicidio; a su vez a san Martín, pontífice de la gracia apostólica, insolentemente apelan nigromante; a Brígida de Escocia, santísima virgen, la llaman maga; en fin, a los venerables padres Antonio, Hilarión, Macario etcétera, aquellos los calumnian con episodios no solo increíbles, sino ridículos. Pero esto a nosotros nada debe empecer. ${ }^{63}$

[...]

Hicieron esto todos los santos, cuyas vidas aquí ofrecemos, con ardentísimo amor, y nos proclaman con ejemplos vivos y al tiempo eficacísimos: «Si queréis contaros entre nosotros, vivid así, como veis que hemos vivido. Sed imitadores nuestros, como nosotros de Cristo». Y aquí realmente nos fortalecemos de manera sólida contra los mortíferos cantos de sirenas, contra las perniciosas voces heréticas, con las que

63. "Etsi autem ab initio fere constitueram instar Aloysii eas duntaxat in Tomos omnes, quos de Sanctis Deo propitio edituri sumus, historias conferre, quae certos probatosque authores haberent: attamen ubi ad rem ipsam perventum est, mutavi sententiam, et quasdam etiam admisi, quorum authores invenire non potui: nec quaslibet tamen, sed quae partim ex vetustissimis Martyrologiis grave habeant testimonium: partim ita scriptae sint, ut cordato lectori per se fidem faciant, satisque ostendant bona fide esse conscriptas, licet vel librariorum incuria, aut illorum, qui eas scripsere, voluntate, aut aliquo alio casu authorum nomina omissa sint. Interim tamen in id genus recipiendis hiftoriis parcior fui: inmo vero per multas omisi, quod parum graviter nec satis ad fidem historiae compositae esse viderentur. Nolui enim impiis haereticis calumniandi occasionem praebere: quanquam non dubito, quae illorum impudentia est, facile inventuros illos, quod in iis quoque historiis lacerent, quae certos, eosque graves habent authores: quarum certe in hoc opere multo maxima pars est. Ita enim illi etiam Paulo et Hilarioni, quorum vitas scripsit beatissimus Hieronymus, partim fidem detrahunt, partim homicidii crimen affingunt: Porro S. Martinum, Apostolicae gratiae pontificem, necromanticum confidenter appellant, Brigidam Scotiae sanctissimam virginem magam vocant: denique illorum priscorum patrum Antonii, Hilarionis, Macarii et c. res gestas non solum incredibiles, sed ridiculas etiam calumniantur. Sed hoc nos remorari nihil debet». 
afirman: «Si puedes creer firmemente que por Cristo todos los pecados te son perdonados, serás salvo; aunque estés envuelto con todos los crímenes, de inmediato volarás directamente al cielo, sin penitencia papística, sin confesión». ${ }^{64}$

[Carta del papa Pío V a Surio, del mismo año 1570, pero incluida en el tomo II, impreso en 1571]:

Recibimos con gran satisfacción el libro que contiene las vidas de los santos padres, recientemente editado por ti, y enviado a nos, el cual sin duda fue incluso más grato a nos por esto, porque contiene en sí una obra siempre deseada por nos, y aptísima para refutar los ultrajes de los herejes contra esas mismas historias de los santos padres. ${ }^{65}$

Y llegamos finalmente a los hagiógrafos postridentinos españoles, cuyos planteamientos se entenderán mucho mejor en relación con todos los textos anteriores. Es lógico que nos preguntemos si los habrían leído Ribadeneira o Villegas, o si en Espańa serían conocidos por los escritores religiosos, o en general por las personas devotas y curiosas. Más allá de la mención expresa que Villegas y Ribadeneira otorgan a Lippomano y Surio como modelos, no será fácil identificar deudas con los participantes en esta controversia, porque muchas son ideas compartidas en cada uno de los bandos, o incluso en ambos bandos. La influencia de los autores protestantes es aún más difícil de detectar, porque cuando los autores españoles recogen contenidos protestantes, no identifican su procedencia; si son ortodoxos, porque no quieren difundir los títulos «herejes», y de ello hemos visto muestras aquí, como cuando Clichtove o Surio no precisan a qué textos en concreto se oponen; y si son heterodoxos, porque enmascaran los pasajes protestantes para no ponérselo fácil a la Inquisición, como sería el caso de Juan de Valdés en el Diálogo de doctrina cristiana, o los menos conocidos de Francisco de Enzinas o Alonso de Zorrilla. ${ }^{66}$ Más allá de lo que se conoce hasta ahora sobre la indudable presencia y persecución del protestantismo en Castilla, queda pendiente la tarea de rastrear los ecos de estos controversialistas en la Espańa de la Edad Moderna entre los escritores religiosos en general y, con más probabilidad de éxito, entre los teólogos académicos.

64. «Fecerunt hoc sancti omnes, quorum Vitas hic proponimus, ardentissimo amore: simulque vivis et efficacissimis exemplis clamant nobis: Si vultis numerari inter nos; sic vivite, ut nos vixisse videtis. Imitatores nostri estote, sicut et nos Chrifti. Atque hic sane validissime communimur adversus mortiferos Sirenarum cantus, adversus exitiosas haereticorum voces, quibus aiunt: $\mathrm{Si}$ potes firmiter statuere, per Christum tibi omnia remissa esse peccata, salvus eris: etiamsi omnibus flagitiis coopertus sis, mox recta evolabis in caelum, sine Papistica poenitentia, sine confessione». 65. «Librum sanctorum Patrum vitas continentem, a te nuper editum, atque ad nos missum, libentissime accepimus: qui quidem eo etiam gratior nobis fuit, quod opus in se continet a nobis semper desideratum, et ad refellenda haereticorum in easdem sanctorum Patrum historias maledicta aptissimum». 66. Me refiero a la Breve y compendiosa institución de la religión cristiana de Francisco de Enzinas, y al De sacris concionibus recte formandis formula, de fray Alonso Zorrilla (véanse García Pinilla 2017 y Baños en prensa). 


\section{Pedro de Ribadeneira}

\section{Vida del P. Ignacio de Loyola, fundador de la religión de la Compañia de Jesús, $y$ de los padres maestros Diego Lainez y Francisco de Borja...}

Contiene un extenso ataque a los herejes, el de mayor alcance de todos los pasajes hagiográficos, y presenta a san Ignacio de Loyola y su fundación como instrumento de defensa de la fe católica frente a ellos, y en concreto frente a Lutero, de manera que convierte a san Ignacio en antagonista de Lutero, aunque realmente no lo fuera, si bien posteriormente la Compañía acabó siendo una importante fuerza contra el protestantismo. ${ }^{67} \mathrm{El}$ extracto de lo más sustancioso de esa diatriba de diez páginas podría ser el siguiente, y basta para percibir la caracterización de los protestantes como monstruos y secuaces del demonio; claro que es lo que cabe esperar cuando Lutero había tachado de Anticristo al papa y había dicho que el papado había sido fundado por el diablo, y cuando su ruptura con Roma había dado paso a las mayores persecuciones religiosas y enfrentamientos armados entre cristianos:

Porque aviendo el miserable y desventurado Martín Lutero (siendo fraile) dexado los ábitos de su religión, y con ellos la vergüença y temor de Dios, y casádose incestuosa y sacrílegamente con una monja, y hecho dello pública fiesta y regozijo, començó a alçar vandera, tocar caxas y hazer gente contra la Iglesia Católica. ${ }^{68}$

Lo primero, han resucitado de allá del infierno donde estavan sepultadas casi todas las heregías y errores que desde el principio del santo Evangelio hasta aora ha avido en la Iglesia de Dios. Apenas en todos los siglos passados ha avido desatino tan loco, ni blasfemia tan horrible, ni dotrina tan impía y diabólica que no aya rebivido en nuestros días por medio de Lutero y sus sequaces: contra la Santíssima Trinidad, contra la divinidad de Jesu Christo, contra la persona del Espíritu Santo, contra la gloriosíssima y sereníssima Reina del cielo nuestra Seńora, contra los ángeles y santos, y ánimas del purgatorio; hasta en el mismo infierno han hallado que mentir, y que blasfemar.

[...]

No se han contentado con enseñar sus diabólicos errores y desvaríos, y con la ponçońa de su dotrina inficionar y matar las ánimas, sino que también con su crueldad y violencia han quitado la vida corporal a muchos, a quien no podían quitar la eterna: a perlados santos, a frailes perfectíssimos, a sacerdotes sagrados, a monjas religiosíssimas, a donzellas honestas y delicadas, a niños innocentes; a viejos por su edad y canas venerables han perseguido, despedaçado, y muerto con estraña crueza, y con tan espantosos y nuevos géneros de tormentos, que los que usaron Diocleciano y Maximiano y otros sangrientos y fieros tiranos para coronar nuestros santíssimos y constantíssimos mártires, apenas llega a ellos. Lea quien quisiere las

67. Goñi (1983: 488-490). Conrod (2013) apunta que en esta vida de san Ignacio el hagiógrafo atiende más lo cotidiano que lo sobrenatural, y relaciona esta característica con el contexto de la Reforma.

68. Ribadeneira (1594 [1572]: 96). 
historias de nuestros tiempos, y hallaralas en lo que toca a lo que vamos tratando llenas de lastimeros sucessos y de crueldades increíbles. A muchas donzellas castíssimas, después de averlas afrentado, por no querer dexar la fe católica, han apretado los pechos entre las arcas o tórculos para que con desapiadados dolores acabassen la vida. Gran número de sacerdotes y religiosos han sido muertos con violencia: unos enterrados bivos, otros despeńados, otros dessollados, otros cozidos o assados bivos, otros traspassados las cabeças con agudíssimos clavos, otros pegando fuego a la pólvora que les avían echado en la boca, abrasados y desmenuzados. ¿Quién creerá que a algunos católicos bivos les sacaron las entrańas y los hizieron pesebres de sus cavallos bravos, llenando el vientre de cevada, para que los comiessen y despedaçassen? ¿Quién que ayan abierto a mugeres preñadas, y sacádoles las criaturas bivas, y dado con ellas en las duras piedras, o en el fuego, o espetádolas y assádolas con fuego manso poco a poco? ¿Quién, que ayan cortado las narizes y orejas de los clérigos y ministros de Dios, y enclavádolas en las cabeçadas de sus cavallos, y traídolas por burla y oprobrio de la orden sacerdotal, con grande braveza y denuesto? ¿Quién que ayan cortado sus miembros, y cozídolos, y héchoselos comer por fuerça a los religiosos viejos y venerables a quien los avían cortado? Pues estas y otras cosas como estas han hecho los calvinistas en Francia en nuestros días.

Si parara en sola la afrenta e injuria de los hombres, esta furia infernal destos diabólicos predicadores no fuera tan horrible y espantosa como es, pero han puesto sus manos sacrílegas en los templos de Dios, en los cálizes, en las vestiduras y vasos sagrados, en la pila del baptismo, en el olio de la unción, en las reliquias de los santos, en el mismo Dios, con increíble desacato, escarnio y vilipendio. No se puede fácilmente creer las iglesias que han derribado y quemado, los monesterios que han assolado y saqueado, el vituperio y oprobrio con que han ultrajado y hollado todos los ornametos e instrumentos sagrados de la Iglesia, ni la impiedad y ravia con que han quemado y hecho polvos los cuerpos de los gloriosos S. Hyreneo, S. Hilario, S. Martín Obispo, santo Tomás Cantuariense, S. Buenaventura, S. Aniano Obispo de Orliens, y derramado y dissipado sus santas reliquias. Han despedaçado las imágenes y cruzes y crucifixos, y hecho fuego dellos, y lo que excede infinitamente todo encarecimiento, y el mismo Satanás temblara en imaginarlo, y solo oírlo haze estremecer las carnes, y es que han tomado muchas vezes la hostia consagrada, en la qual estava verdadera y realmente el cuerpo de nuestro Salvador Jesu Christo ( $\mathrm{o}$ [h] bondad immensa, o[h] clemencia y paciencia de Dios infinita!) y la han tratado con tan grande desacato que no se puede escrivir.

Aquí se agota el entendimiento, y enmudece la lengua, y desfallece y se acaba el sentido de qualquiera persona que tiene una pequeña centella de fe. ${ }^{69}$

Estos pues son algunos de los innumerables frutos deste nuevo Evangelio, y no es maravilla que sean tales qual es el árbol donde ellos nacen, y que el agua tenga el sabor de la fuente de donde ella mana. El espíritu de todos los hereges es espíritu de libertad, de blasfemia, de maledicencia, de tiranía, de crueldad y de sobervia, porque es espíritu de Satanás que en ellos se reviste; y el de Lutero y sus dicípulos es más abominable y más perverso que ninguno de todos los hereges passados. Y para que sepamos claramente sin que se pueda poner duda quién era el que le movía y guiava en lo que pensava, dezía y hazía contra la Iglesia Católica, él mismo confiessa y escrive 
que conocía al demonio, y que avía comido algunos celemines de sal con él, y que muchas vezes le aparecía, y argüía y disputava con él, y le proponía razones sofísticas y argumentos falsos y aparentes contra las verdades maziças y antiguas de nuestra santa religión, y especialmente contra el sacrosanto sacrificio de la missa, y contra la reverencia y acatamiento que se deve a tan soberano y divino misterio. Desta dotrina y maestro han brotado como de su raíz y fuente los desacatos tan diabólicos que contra él han usado sus dicípulos. Aunque para dezir la verdad, ellos han sido tales, que con ser su maestro Lutero tan horrible monstruo como parece por sus obras, no tiene que ver con los calvinistas y ugonotes sus dicípulos en la impiedad, violencia, crueldad y tiranía, los quales no se han contentado de perseguir la religión católica y a los que la professan, sino que alborotan y destruyen y assuelan todas las provincias y reinos donde entran, como enemigos capitales que son del género humano, y con verdad se puede llamar incendio y pestilencia universal del mundo.

[...]

Bolviendo pues a nuestro propósito, y declarando el intento que Dios nuestro Señor tuvo en fundar la Compañía, y la necessidad que avía de quien resistiesse a los hereges (que para que esto se entendiesse mejor, se ha hecho este, si se mira a lo que es, largo, y si a lo que se puede dezir breve y compendioso discurso), quando salió del abismo Martín Lutero, como monstruo infernal, acompañado de un esquadrón de abominables y diabólicos ministros para hazer los efectos que avemos visto y otros semejantes, que por ser innumerables se dexan de contar, y para llevar tras sí, a guisa de otro dragón que cae del cielo, la tercera parte de las estrellas, al mismo tiempo embió Dios nuestro Señor de socorro otro varón, y capitán a su Iglesia en todo, y por todo contrario a Lutero, para que con su espíritu invencible y armas poderosas y divinas valerosamente le resistiesse y peleasse las batallas del Señor. ${ }^{70}$

\section{Alonso de Villegas}

Flos sanctorum y historia general de la vida y hechos de Jesuchristo, Dios y Señor nuestro, y de todos los Santos de que reza y haze fiesta la Iglesia Católica, conforme al Breviario Romano, reformado por decreto del Santo Concilio Tridentino

Villegas aspira a que su obra sea reconocida como el Flos sanctorum reformado en español, y por ello declara ajustarse al Breviario Romano reformado tridentino, siguiendo la pauta de Surio, como hemos visto. También el contenido bebe de Lippomano y Surio. ${ }^{71}$ Cuando se refiere a la «irrisión» que provocan los pasajes apócrifos, Villegas parece evocar la dedicatoria de Lippomano (1551), si no también directamente (aunque eso no parece probable) a Lutero y Major (1544):

[Dedicatoria a Felipe II]:

Quédale ahora a vuestra M. otra cosa que mandar, no menos importante y necessaria en su razón: y es se reforme el Flos sanctorum, libro donde están las historias y vidas de los santos, de que en el oficio divino se haze mención. Porque dexando aparte que

70. Ribadeneira (1594 [1572]: 103-105).

71. Greenwood (2018: 184 y 191-192) advierte que no debe pasarse por alto la influencia de Simeón Metafrastes, una de las fuentes de Lippomano, y que por tanto había pasado en cadena, con los cambios de cada caso, a Surio, Villegas y Ribadeneira. 
en los libros deste nombre que ahora andan, se leen muchas cosas apócrifas, y agenas de toda verdad, léense también otras muchas tan faltas de la autoridad y gravedad que pide semejante letura, que antes provocan a irrisión que a devoción, las cuales dan bastante causa a gentes de otras naciones para que burlen de los españoles, porque en su lengua no tienen cosa grave y de autoridad, en materia de tanta importancia.

\section{Alonso de Villegas}

Fructus sanctorum, y quinta parte de flos sanctorum, que es libro de exemplos

Ataque a los herejes protestantes, del tenor del de Ribadeneira de 1572, pero mucho más breve, aunque suficiente para caracterizar a los protestantes como monstruos:

[Ejemplo 37] Justo juizio de Dios es que todos los hereges paren en mal, y que aun en esta vida aya muestras evidentes de que van a la otra a fuegos eternos. Y desto ay exemplos modernos como fue uno el infernal mostruo y heresiarca perniciosíssimo Martín Luthero. [...] Después, el año de mil y quinientos y veinte y tres, dexó el hábito y se casó, y hablando propriamente se amancebó con Catharina Bore, que avía sido monja professa en el monasterio de Torgobia, a la cual Leonardo Coppen sacó con otras ocho monjas un Viernes de la Cruz del monasterio y las truxo dos años por burdeles, y no por esso le puso asco al apóstata luxurioso y sucio ver que huviesse tenido tienda pública de su persona, para dexar de casar, esto es, amancebarse con ella. Levantó este endiablado hombre perversas y sacrílegas heregías. [...] el sacrílego y endiablado Luthero, acostándose una noche bueno, a la mañana fue hallado muerto, con un rostro espantable, que no avía quien sin temor osasse mirarle. Calvino, otro heresiarca, cuando moço fue castigado por el pecado nefando, con ponerle un hierro ardiendo en el hombro. Y después de aver hecho en Francia el daño que Lutero en Alemaña, vino a morir en Géneva, comido de gusanos, despedaçándose a bocados sus carnes, diziendo terribles blasfemias. ¡Santo Dios, y que aya gente tan ciega que dé crédito a tales mostruos infernales! ${ }^{72}$

\section{Pedro de Ribadeneira}

Flos sanctorum, o libro de las vidas de los santos

Es el santoral castellano que compite con el de Villegas, aunque con menos ambición en lo tocante a la cantidad de vidas y quizá también a la popularidad. ${ }^{73}$ Sigue asimismo a Lippomano y Surio. Aquí Ribadeneira presenta el Flos sanctorum como arma contra los herejes:

72. Villegas (1594: 168r).

73. Greenwood (2018: 196-197) compara los flores sanctorum de Villegas y Ribadeneira; da cuenta de la diferencia en cantidad de vidas (640 Villegas y 405 Ribadeneira) y observa asimismo que Villegas utiliza ilustraciones, mientras que Ribadeneira apenas, lo que podría ser un indicio de que Villegas pretende un público más amplio. 
[Prólogo al lector]:

Es assí mismo de grandíssima gloria para toda la Iglesia Católica, saberse los innumerables y esclarecidos hijos que ha tenido. [...] Demás desto, es un fuerte escudo y defensa contra los infieles que la contrastan, y un martillo y cuchillo contra los hereges, cuyos errores y desatinos con ninguna cosa se convencen mejor que con los exemplos de los santos. Porque es más excelente modo de enseñar con obras que con palabras, y las obras de los santos son santas, y contrarias en todo y por todo a los disparates y desvaríos de los hereges. Y assí para convencerlos e interpretar las cosas dudosas y lugares difíciles de las divinas letras es gran luz la vida y exemplos de los santos, que por esto dixo san Gerónimo: «Vita sanctorum, interpretatio est Scripturarum». ${ }^{74}$

\section{Conclusiones}

Al poner en relación los textos que aquí se extractan, se comprende la conveniencia de distinguir tres planos en este asunto del culto a los santos y la ruptura de la Iglesia, una distinción que muestra matices de coincidencia entre ambos bandos, en principio radicalmente enfrentados:

1. En el plano personal y político existe una virulencia extrema, que empieza con la rebeldía de los protestantes e intentos de sometimiento por parte de la jerarquía católica, prosigue con la quema de escritos, evoluciona hacia las invectivas descarnadas y terminará con la guerra. En lo tocante a los autores aquí tratados, Lutero ataca al papa y al papado, y en respuesta los hagiógrafos católicos contraatacan y retratan a los protestantes como herejes monstruosos.

2. En el plano teológico, la polarización también es clara, pues Lutero se opone al culto a los santos, y la Iglesia Católica, como era de esperar, lo reafirma. No obstante, en este plano caben los matices que hemos visto, como que los luteranos niegan a los santos la condición de intercesores, pero acaban recurriendo a ellos como fuente de dichos y hechos edificantes para los fieles; reconocen pues a los santos como modelo de sabiduría y virtud, centradas ambas en la fe y en la confianza en la gracia de Dios. Por su parte en el Concilio de Trento se defiende la intercesión de los santos, la veneración de las reliquias, la utilidad de las imágenes, la ejemplaridad de sus vidas y milagros, pero también se advierte de la necesidad de evitar toda superstición, todo negocio sórdido y toda torpeza.

3. En el plano hagiográfico, podemos diferenciar dos periodos en los que ambos bandos pasan de estar radicalmente enfrentados a coincidir en algunos aspectos. El primer periodo es el del Lutero hagioclasta que persigue las vidas de santos, tanto en escritos propios como en otros de teólogos afines. El segundo el del Lutero hagiógrafo por vía vicaria. En esta segunda fase el bando protestante y el católico confluyen en que las vidas de santos son lec-

74. Ribadeneira (1616 [1599]: 2-3). 
tura edificante, si se purgan de falsedades y supersticiones. Podríamos haber dicho que coinciden, si no fuera porque los protestantes solo recogen de la tradición hagiográfica lo que sirve a su doctrina, y los católicos consideran esta manipulación de la tradición hagiográfica una nueva blasfemia. Además, como hemos visto a propósito de Surio y podría extenderse también a Villegas y a Ribadeneira, forma parte de la reafirmación católica que los hagiógrafos incluyan los milagros y otros prodigios cuando provengan de una fuente autorizada, aunque ocasionalmente también admitan episodios procedentes de fuentes de menor credibilidad.

Si centramos la cuestión en el ámbito castellano, este estudio muestra que las declaraciones de intención de Villegas y de Ribadeneira solo se entienden plenamente al cotejarlas con las de Lippomano y Surio, un hagiógrafo italiano y otro alemán que trabajan espoleados por el deseo de oponerse a los protestantes y más en concreto a sus planteamientos sobre la hagiografía. El impacto de la Reforma en la hagiografía castellana es notorio. 


\section{Bibliografía}

AragüÉs Aldaz, José, «El santoral castellano en los siglos XVI y XVII. Un itinerario hagiográfico", Analecta Bollandiana, 118 (2000), 329-386.

—, «Para el estudio del Flos Sanctorum Renacentista (I). La conformación de un género", Homenaje a Henri Guerreiro. La hagiografia entre historia y literatura en la España de la Edad Media y del Siglo de Oro, ed. Marc Vitse, Madrid/Frankfurt, Universidad de Navarra / Iberoamericana-Vervuert, 2005, 97-147.

—, «La difusa autoría del Flos sanctorum: silencios, presencias, imposturas», El autor oculto en la literatura española: siglos XIV a XVIII, ed. Maud Le Guellec, Madrid, Casa de Velázquez, 2014, 21-40.

Arronis Llopis, Carme, «La evolución del género de las vidas de María en el siglo XVI», Studia Aurea, 11 (2017), 273-296.

BaCKus, Irena, Life Writing in Reformation Europe: Lives of Reformers by Friends, Disciples and Foes, Cornualles (Reino Unido), Ashgate, 2008.

Baños Vallejo, Fernando, "Paratextos, ilustración y autoridad en los flores sanctorum castellanos del siglo XVI", Versants. Revista suiza de literaturas románicas, 65, 3, fascículo español (2018), 33-61.

—, «El Diálogo de doctrina cristiana como obra apócrifa y otras cautelas de Juan de Valdés», Revista de Filología Española, en prensa.

Bischof, Franz Xaver, y Harry Oelke, eds., Luther und Eck: Opponenten der Reformationsgeschichte im Vergleich, Munich, Allitera, 2017.

Brady, James F., y John C. Olin, eds., Collected Works of Erasmus. Volume 61: Patristic Scholarship. The Edition of St. Jerome, Toronto, University of Toronto Press, 1992.

Burkert, Martin, y Karl-Heinz Röhlin, Georg Spalatin: Luthers Freund und Schutz, Leipzig, Evangelische Verlagsanstalt, 2015.

Chomarat, Jacques, «La Hieronymi Stridonensis Vita d'Erasme», Helmantica: Revista de filología clásica y hebrea, 50 (151-153), 1999, 109-138.

Civil, Pierre, "Religiosité populaire et religiosité des élites à travers les Flos sanctorum de la fin du XVI ${ }^{\mathrm{e}}$ siècle», Relations entre identités culturelles dans l'espace ibérique et ibéro-américain, dir. Augustin Redondo, vol. 2, París, Presses de la Sorbonne Nouvelle = Cahiers de l'UFR d'Études Ibériques et Latino-Américaines, 11 (1997), 77-94.

Clichtove, Josse van, De veneratione sanctorum, París, Simonis Colinaei, 1523.

Collins, David J., Reforming Saints. Saints' Lives and Their Authors in Germany, 1470-1530, Nueva York, Oxford University Press, 2008.

Concilio de Trento $(1545-1563)=$ El sacrosanto y ecuménico Concilio de Trento, edición, traducción del latín y notas de I. López de Ayala, Barcelona, Ramón Martín Indar, 1847.

Conrod, Frédéric, «The Greatest Collector: Ribadeneira’s Hagiography of Loyola as Struggle Against Dispersion», Hispanic Review, 81 (1), 2013, 1-16. 
Dingel, Irene, y Günther Wartenberg, eds., Georg Major (1502-1574). Ein Theologe der Wittenberger Reformation, Leipzig, Evangelische Verlagsanstalt, 2005.

Ditchield, Simon, "Tridentine Worship and the Cult of Saints», The Cambridge History of Christianity. Volume 6: Reform and Expansion 15001660, ed. R. Po-Chia Hsia, Cambridge University Press, 2007, 201-224.

Dyкema, Bobbi, Luther, Cranach, and the Passional Christi und Antichristi, Saarbrücken, Lambert Academic Publishing, 2017.

Eск, Johann, Enchiridion locorum communium adversus lutheranos, [Colonia], [Peter Quentel], 1525. La edición moderna de Pierre Fraenkel abarca revisiones posteriores: Enchiridion locorum communium adversus Lutherum et alios hostes ecclesiae: (1525-1543), Münster, Aschendorff, 1979.

Erasmo de Rotterdam, Eximii Doctoris Hironymi Stridonensis vita, ex ipsius potissimum literis contexta, Basilea, Johannes Frobenius, 1519.

García Pinilla, Ignacio Javier, «Los primeros testimonios de la influencia de Lutero en España», Anales Valentinos, 7 (2017), 85-105.

GoÑ I Gaztambide, José, «La imagen de Lutero en España: su evolución histórica», Scripta Theologica, 15 (2), 1983, 469-528.

Greenwood, Jonathan E., «Floral Arrangements: Compilations of Saints' Lives in Early Modern Europe», Journal of Early Modern History, 22 (3), 2018, 181-203.

Guillausseau, Axelle, «Des hagiographies collectives au service de l'universalisme tridentin? Réflexions sur les trajectoires editoriales des Flos sanctorum d'Alonso de Villegas et de Pedro de Ribadeneyra", La Cour céleste. La commémoration collective des saints au Moyen Áge et à l'époque moderne, ed. Olivier Marin y Cécile Vincent-Cassy, Turnhout, Brepols, 2014, 117-125.

Hoogstraten, Jacob van, Dialogus de veneratione \& invocatione sanctorum, contra perfidiam lutheranam, Colonia, Peter Quentel, 1524.

Jardine, Lisa, Erasmus, Man of Letters. The Construction of Charisma in Print, Princeton University Press, 1993.

Kessler, Hans Joachim, Georg Spalatin: Geheimdiplomat der Reformation, Taucha, Tauchaer, 2017.

Kimmig-Völkner, Susanne, «Luther, the Virgin Mary, and the Saints. Catholic Images as a Key to Understanding the Lutheran Concept of Salvation", Martin Luther and the Reformation. Essays, Dresden, Sandstein, 2016.

Lippomano, Luis, Sanctorum priscorum patrum vitae, numero centum sexagintatres, per gravissimos et probatissimos auctores conscriptae, Venecia, Ad Signum Spei, 1551.

Lonitzer, Johann, Catechesis de bona Dei voluntate erga quemvis Christianum, deque Sanctorum cultu \& invocatione, [Estrasburgo], [Johann Schott], [1523].

Lutero, Martín, Las noventa y cinco tesis [1517], vid. Lutero, Martín, Obras de Martín Lutero.

- A la nobleza cristiana de la nación alemana acerca del mejoramiento del estado cristiano [1520], vid. Lutero, Martín, Obras de Martín Lutero. 
—, La cautividad babilónica de la Iglesia [1520], vid. Lutero, Martín, Obras de Martín Lutero.

-, Contra el nuevo idolo y antiguo demonio que será elevado en Meissen, Witenberg, Hans Lufft, 1524.

-, A toda la clerecía reunida en Augsburgo para la dieta del año 1530, vid. Lutero, Martín, Obras de Martín Lutero.

-, Obras de Martín Lutero. Tomo I, trad. Carlos Witthaus, Buenos Aires, Facultad Luterana de Teología, Paidós, 1967.

-, Contra el papado de Roma, fundado por el diablo, introducción, traducción del alemán y notas de Gabriel Tomás, Barcelona, Createspace, 2014 [1545].

-, Contra Juan Salchicha (Hans Wurst), introducción, traducción del alemán y notas de Gabriel Tomás, Barcelona, Createspace, 2016 [1541].

Lutero, Martín, y Lucas Cranach, el Viejo (grabados), Imagen del papado, Witenberg, 1545.

Major, Georg, Vitae Patrum, in usum ministrorum verbi, quoad eius fieri potuit repurgatae, con prólogo de Martín Lutero, Witenberg, Peter Seitz, 1544.

Malysz, Piotr J., "Reception of Doctrine as a Methodological Issue in Early Lutheranism", Lutheran Theology: An Online Journal, 2009.

Rex, Richard, The Making of Martin Luther, Princeton University Press, 2017.

Ribadeneira, Pedro de, Vida del P. Ignacio de Loyola, fundador de la religión de la Compañía de Jesús, y de los padres maestros Diego Lainez y Francisco de Borja..., Madrid, Pedro Madrigal, 1594 [1572 primera edición en latín, en castellano en 1583].

-, Flos sanctorum, o libro de las vidas de los santos, primera parte, Madrid, Luis Sánchez, 1616 [1ª ed. 1599].

Rienm, Heidrun, Sternbilder des Glaubens oder Abgötter? Martin Luthers Stellung zur Verehrung der Heiligen, Marburgo, Tectum, 2010.

Spalatin, Georg, Magnifice consolatoria exempla et sententiae, ex vitis et passionibus sanctorum et aliorum summorum virorum, brevissime collectae, opera, con prólogo de Martín Lutero, Witenberg, Nicolai Schirlent, 1544.

STEIgER, Johann Anselm, Christophorus: ein Bild des Christen. Heiligengedenken bei Martin Luther und im Luthertum der Frühen Neuzeit, Neuendettelsau, Freimund, 2012.

Surio, Lorenzo, De probatis sanctorum historiis, t. 1, Colonia, Gervino Calenio y herederos de Quentelio, 1570.

Tomás, Gabriel, ed., Martín Lutero, Contra el papado de Roma, fundado por el diablo, Barcelona, Createspace, 2014.

-, Contra Juan Salchicha (Hans Wurst), introducción, traducción del alemán y notas de Gabriel Tomás, Barcelona, Createspace, 2016.

Villegas, Alonso de, Flos sanctorum y historia general de la vida y hechos de Jesuchristo, Dios y Señor nuestro, y de todos los Santos de que reza y haze fiesta la Iglesia Católica, conforme al Breviario Romano, reformado por decreto del Santo Concilio Tridentino, vol. 1, Madrid, Pedro Madrigal, 1588 [1ª ed. 1578]. 
-, Fructus sanctorum, y quinta parte de flos sanctorum, que es libro de exemplos, Cuenca, Christiano Bernabé, 1594.

Wengert, Timothy J., «The Ninety-Five Theses as a Literary and Theological Event", Lutherjahrbuch, 85 (2018), 37-60.

Witzel, Georg, Hagiologium seu de sanctis Ecclesiae, Maguncia, Franciscus Behem, 1541. 